\title{
VIEWPOINT
}

\section{Heritage in the Street: Megawra | BEC's Athar Lina Initiative in Historic Cairo}

\author{
May al-lbrashy \\ Megawra | Built Environment Collective, Egypt \\ info@megawra.com
}

\begin{abstract}
Based in al-Khalifa in Historic Cairo and run by the Megawra-Built Environment Collective, Athar Lina is a participatory initiative to establish modalities of citizen participation in heritage conservation based on a vision of heritage as a resource not a burden. Since its inception in 2012, Athar Lina has worked on conservation, heritage education, urban revitalization and heritage industries. It has conserved four domes from the I2th and I4th century and is currently working on the conservation of two other monuments including al-Imam al-Shafi'i shrine. It runs an Open-Spaces Program focusing on improving infrastructure and services to upgrade quality of open spaces. This is directly linked to Athar Lina's Ground Water Research Project which seeks to resolve problems of groundwater-rise in heritage sites by extracting water and reusing it for the benefit of the community for purposes such as irrigation and cleaning. In addition to its Heritage Education Program and the Heritage Summer School it runs for al-Khalifa's children, it runs the Athar Lina Heritage Design Thinking School which explores the potential of heritage for income-generation. Finally, through its research and advocacy project, Citizen Participation in Historic Cairo, Athar Lina is working on conservation, revitalization and management plans for al-Khalifa.
\end{abstract}

Keywords: heritage management, community development, conservation, participation, historic Cairo

To cite this article:

al-Ibrashy, M. (202I) Heritage in the Street: Megawra | BEC's Athar Lina Initiative in Historic Cairo, The Journal of Public Space, 6(I), 24I-256, DOI I0.3289I/jps.v6il.I462

This article has been reviewed by the Editors and accepted for publication in The Journal of Public Space.

This work is licensed under a Creative Commons Attribution - Non Commercial 4.0 International License https://creativecommons.org/licenses/by-nc/4.0/ 


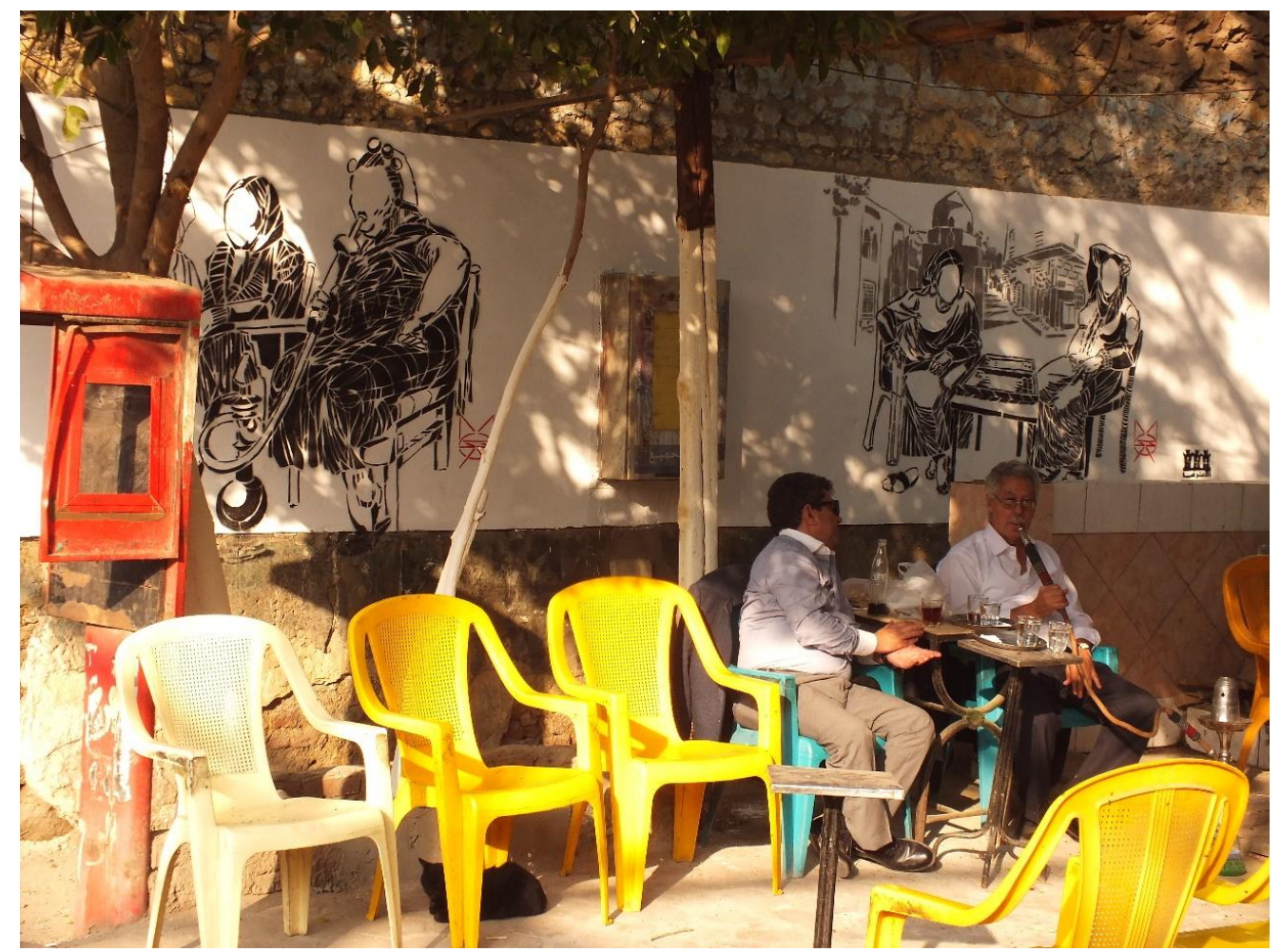

Figure I. Al-Khalifa Women Mural designed and implemented by Agnes Michalczyk @ A Athar Lina

\section{A mural of women in a men-only coffeeshop in Historic Cairo}

In 2013, Agnes Michalczyk, a Polish-Egyptian Artist proposed a mural to be painted on the wall of a coffeeshop in al-Khalifa Street in Historic Cairo. The mural was of a group of Rubenesque middle-aged women dressed in traditional Egyptian galabiyyas (loose floor length tunics) and smoking shisha (waterpipes). In the background of the mural, another group of even more extraordinary women are represented through the domes built in their honour; Shajar al-Durr Dome, built in I 250 to commemorate Islamic Egypt's only female ruler and al-Sayyida Ruqayya Dome, built in II 44 by another woman in honour of a pious woman and descendant of the Prophet Muhammad. The actual domes are only a stone's throw away and they are as familiar as old friends to the bunch of old men who meet daily in the coffeeshop. Not as familiar though, is the sight of women smoking shisha in traditionally male street-side coffeeshops in Cairo.

The proposed mural was part of a set of activities to celebrate the heritage of al-Khalifa Street, a street known for its wealth of heritage sites. The street is most famous for the $9^{\text {th }}$ century Ahmad Ibn Tulun Mosque, one of Egypt's oldest and most iconic mosques, and for its religious sites of visitation, the most famous of which is al-Sayyida Nafisa Mosque and Shrine. The event was to be called (Spend Your Day in Khalifa) and it marked the launch of several projects to be implemented by Athar Lina Initiative.

Activities focusing on heritage conservation, heritage education, heritage industries and urban development were carried out under the umbrella of Megawra-Built Environment Collective and in partnership with the Egyptian Ministry of Antiquities.'

\footnotetext{
' Now part of the Ministry of Tourism and Antiquities.
} 


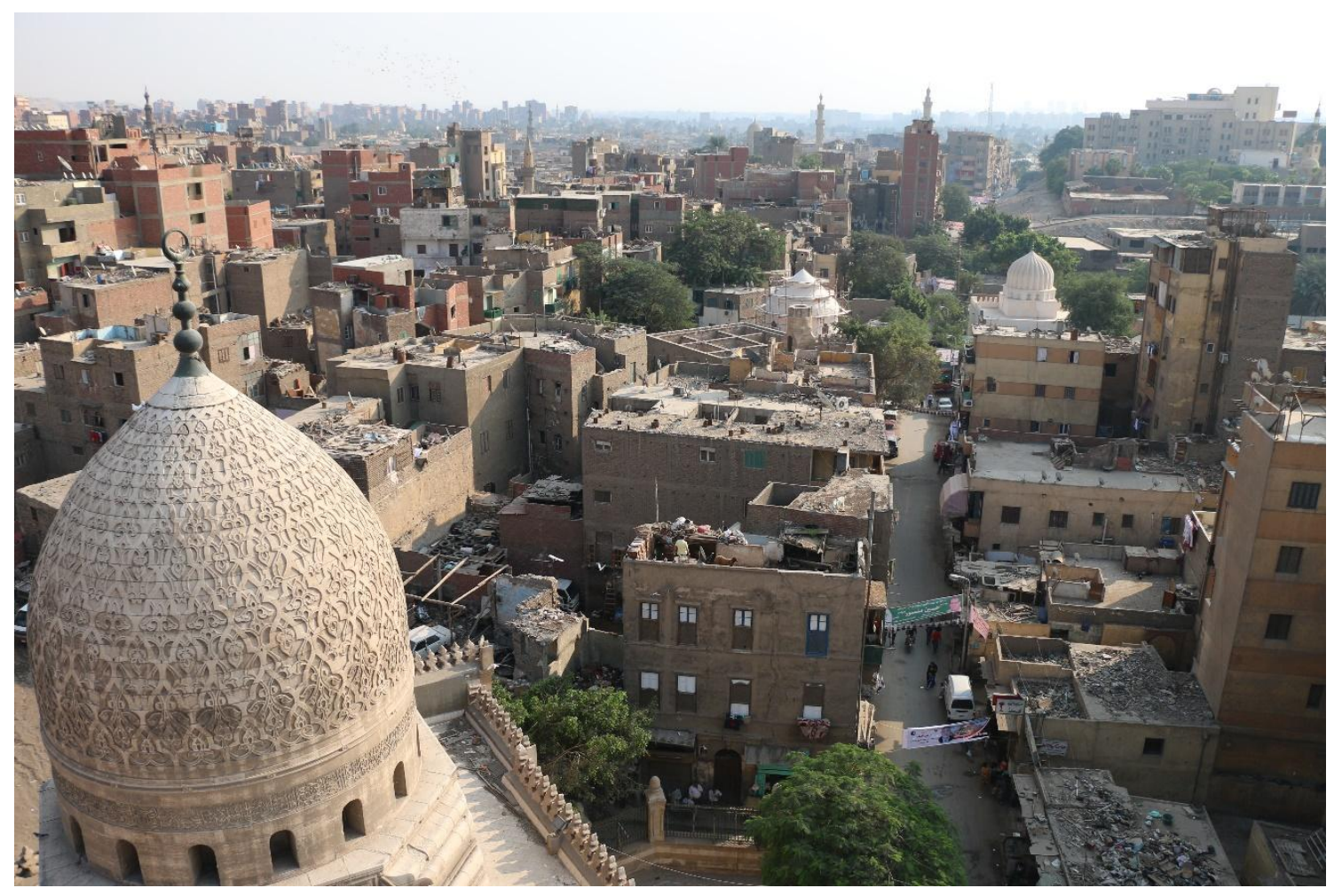

Figure 2. View of al-Khalifa Street Area from al-Sayyida Sukayna Mosque @ Maram Adel

\section{Athar Lina Initiative}

One year prior, in 2012, the team of Athar Lina had organised a series of participatory research and design meetings to study the relationship between the heritage of the street and the community. ${ }^{2}$ The question was concerning the lack of participation of the community in conserving their neighbourhood's heritage. The premise was that they felt alienated from it and that their sense of ownership of heritage had been severed through a chain of misconceived heritage policy decisions by a State that treated them as adversaries rather than custodians of their own heritage. The assumption was that people would regain their sense of ownership if they felt they benefitted from their heritage. Benefit could be economic, social, cultural, or spiritual. The question was how to go about rebuilding that proprietary relationship.

By the end of 2012 - and after 6 months of discussion between residents, government officials, academics, professionals and heritage advocates - we concluded that action could be taken to reconnect heritage to the community by conceiving of it as a driver for development. This action should take the form of heritage education, conservation and rehabilitation of historic buildings for the benefit of the neighbourhood and that these actions should be grounded in socio-economic and urban development that manages and utilises heritage in a manner that improves quality of life in the city.

\footnotetext{
${ }^{2}$ Implemented in 2012 with a personal grant from the Danish Egyptian Dialogue Institute.
} 


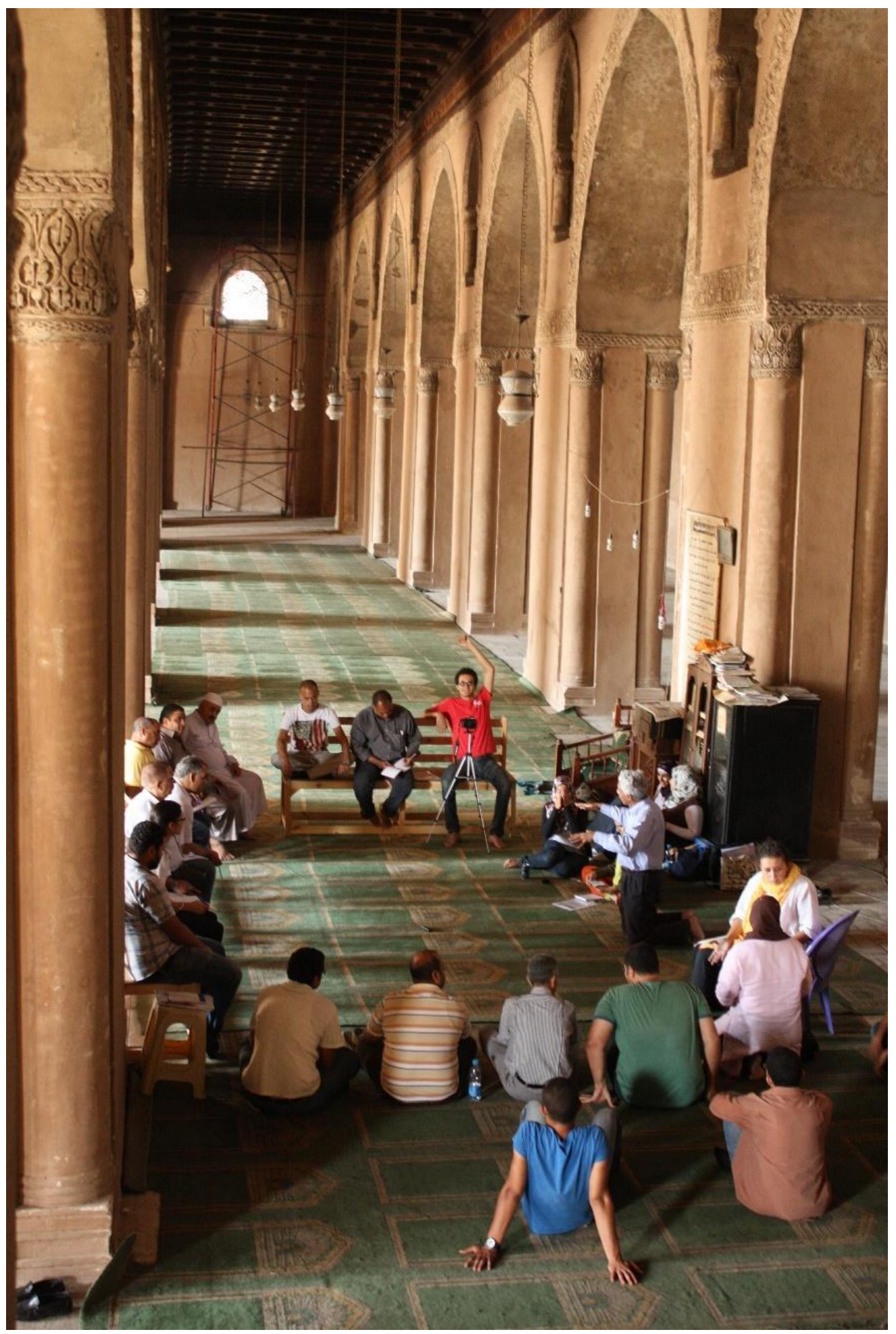

Figure 3. Stakeholder meeting in Ibn Tulun Mosque (C Athar Lina 


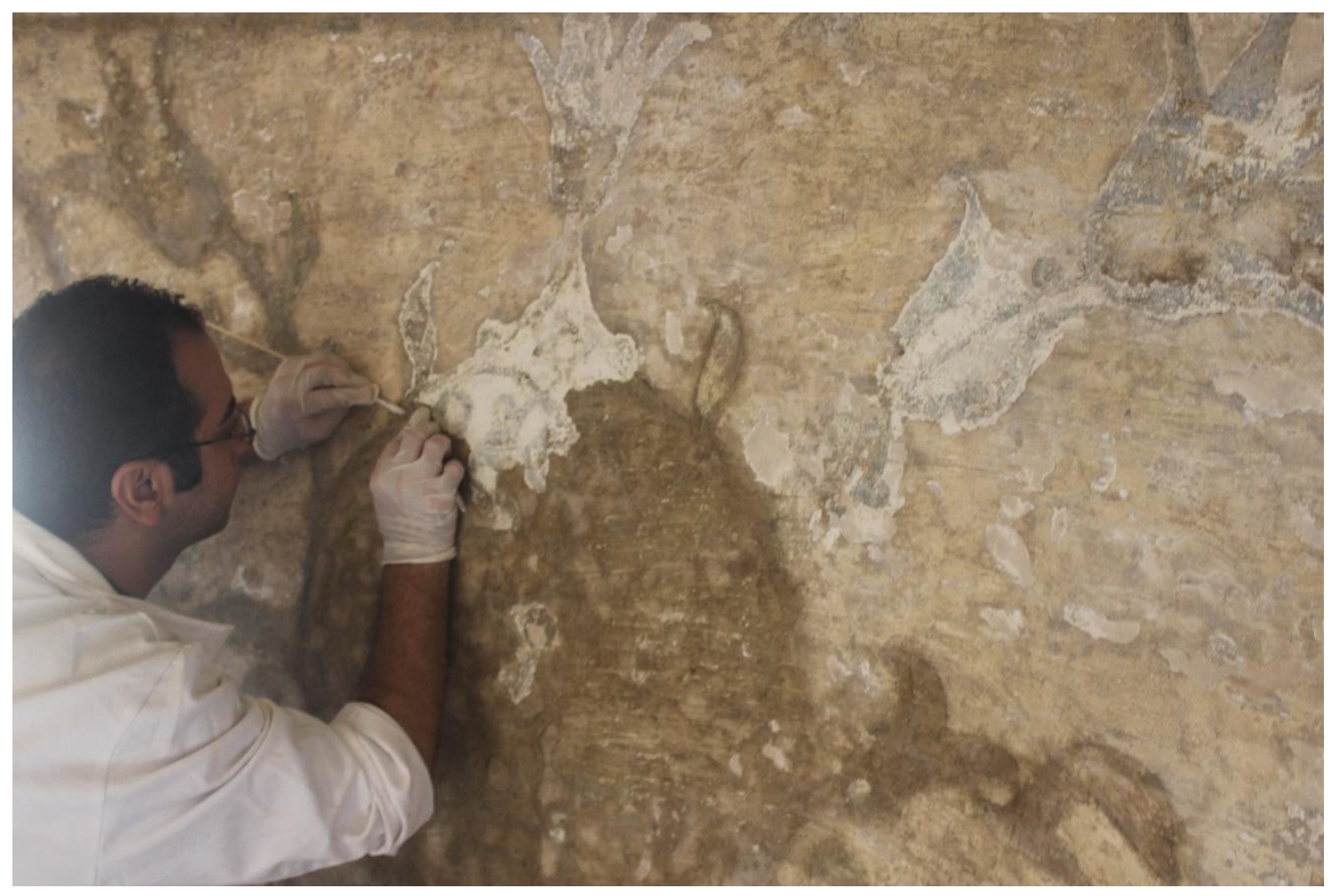

Figure 4. Decorative stucco conservation - Shajar al-Durr Conservation Project @ Athar Lina

By the time the mural of the shisha-smoking women was being considered, Athar Lina Initiative had conducted a heritage education program in one of the local primary schools, and started preparing for its own heritage summer camp for local children in an early $20^{\text {th }}$ century building it was rehabilitating for that purpose. It had also obtained funding for the first in the line of a series conservation efforts, Shajar al-Durr Dome Conservation Project ${ }^{3}$. The team had already understood that one of the hazards of development work was the failure to understand the dynamics of the neighbourhood of intervention. Socio-economic patterns needed to be studied, tapped into, and built on. Insensitive actions, however small, could cause a ripple effect that could undermine the work in its entirety. This is why we were apprehensive of the radical choice of artist, however well-justified, to push a feminist agenda and impose women onto the sphere of public space if only through visual representation. The coffee-owner, however, was delighted. 'Amm Mustafa, a 60-something gruff man loved the drawing and his judgment proved to be sounder than ours. The women were not just accepted; they were appreciated and soon became a landmark that brought the coffee shop more business. It became common for strangers visiting the neighbourhood, for its many mawlids (saint day celebrations) for example, to meet at "the coffeeshop with the women".

\footnotetext{
${ }^{3}$ Implemented between 2013 and 2015 in partnership with the Egyptian Ministry of Antiquities and with funding from the American Research Centre in Egypt with additional funding from the Barakat Trust.
} 


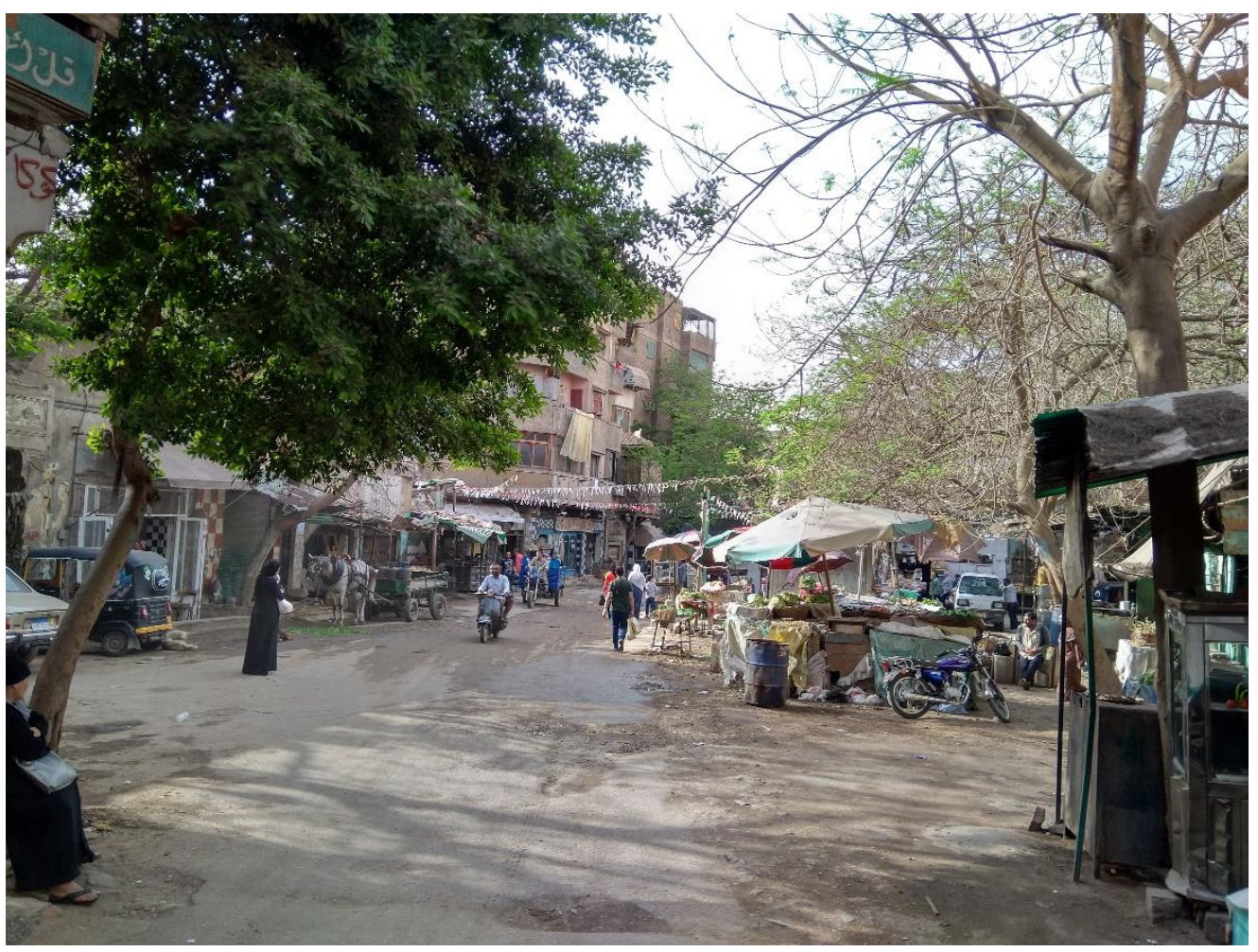

Figure 5. Market street in al-Khalifa (C) Athar Lina

\section{Urban issues in al-Khalifa}

This was one of the first lessons we learned on the importance of art interventions in public space and their value as a tool for experimentation and trust-building. When we started working in al-Khalifa, we did so primarily out of appreciation for its heritage as one of the most significant neighbourhoods within the World Heritage Site of Historic Cairo. We understood - and advocated for - the importance of bringing communities to the forefront of the struggle to preserve and manage heritage but we were also daunted by the complexities of its urban setting. In addition to struggling to understand socio-economic dynamics, any attempt at renovating residential buildings or improving public space was thwarted by infrastructure issues, most notably rising groundwater, and service problems such as waste management. This was in addition to the fact that right to public space was arbitrary, given and taken at the caprice of the State, and that certain members of the community, women and children in particular, were less entitled to it than others. With street art, whether performative or visual, we were able to circumvent endemic issues and add beauty and joy to public space. We could try out new ideas and learn from them through temporary installations. We could deliberately target the marginalised and under-represented. And we could connect with the community over human values of art and play. 


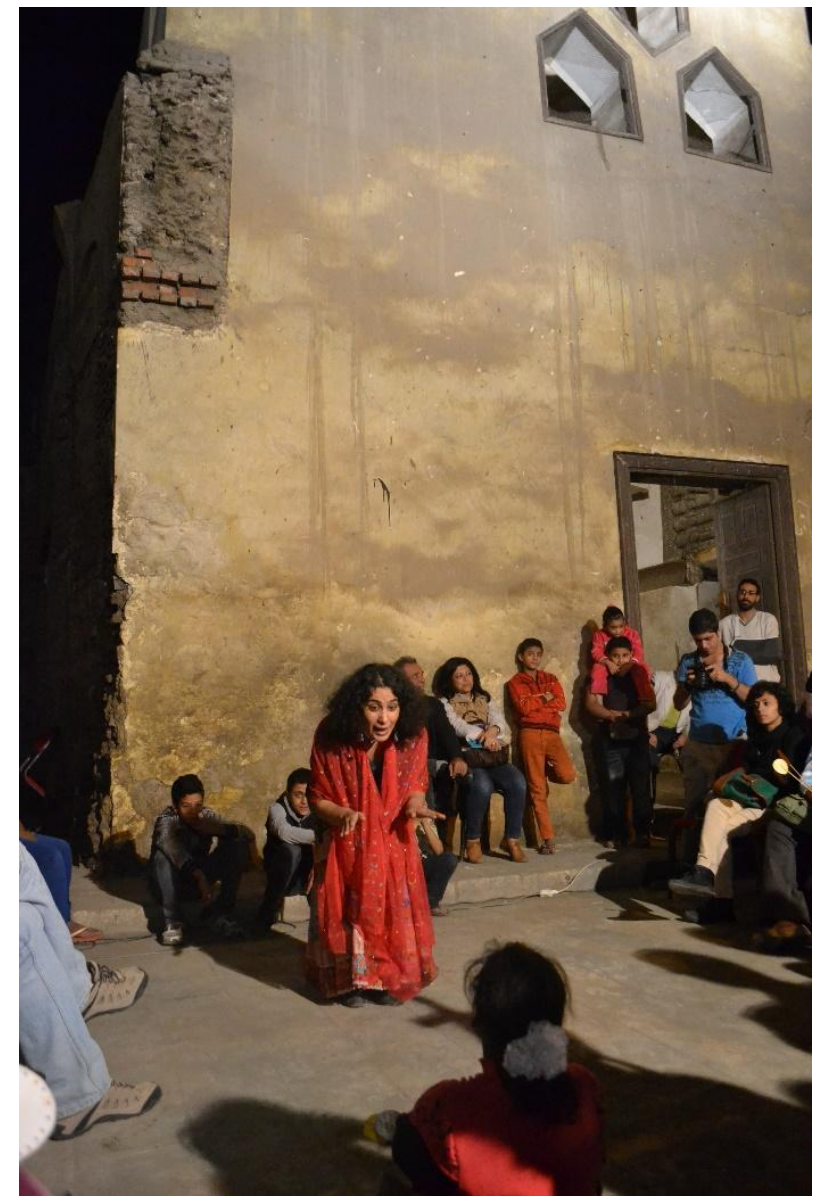

Figure 6. Storytelling performance by Chirine El-Ansary (C) Athar Lina

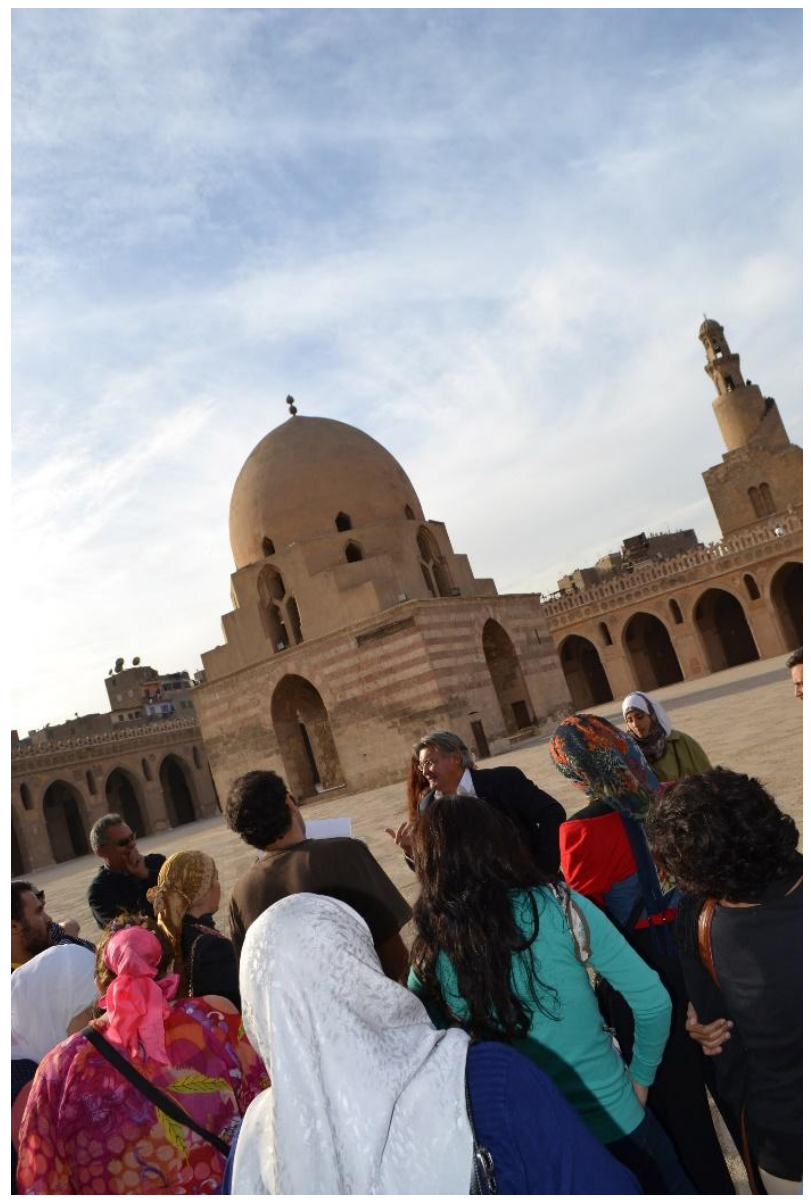

Figure 7. Guided tour through Ibn Tulun Mosque conducted by Tarek Swelim (C) Athar Lina

\section{Spend Your Day in Khalifa}

Since 2013, we have organized seven Spend Your Day in Khalifa (SDYK) festivals. Their geographical reach has extended beyond al-Khalifa Street to include other

neighbourhoods in the wider al-Khalifa District, namely al-Hattaba, a historic residential neighbourhood north of the Citadel wrongly categorised as an informal settlement and threatened with evacuation and demolition, and the historic cemetery of al-Imam alShafi'i, part of Cairo's so-called City of the Dead. We have organised music, storytelling, dance and circus acts in the street, curated heritage inspired murals and signage, exhibited arts and crafts, run guided tours and interactive heritage education activities, brought children and youth together through sports, inaugurated our conservation and urban upgrade projects and promoted causes such as the rights of Syrian immigrants to culture and heritage. Close to 200 Syrian and Egyptian children participated in interactive visits to historical sites in the neighbourhood of al-Khalifa in Historic Cairo, discussed history within themes that centred on the meaning of family, the family home, the value of play and the benefits of travel, and expressed their understanding of these issues through storytelling and visual art. 


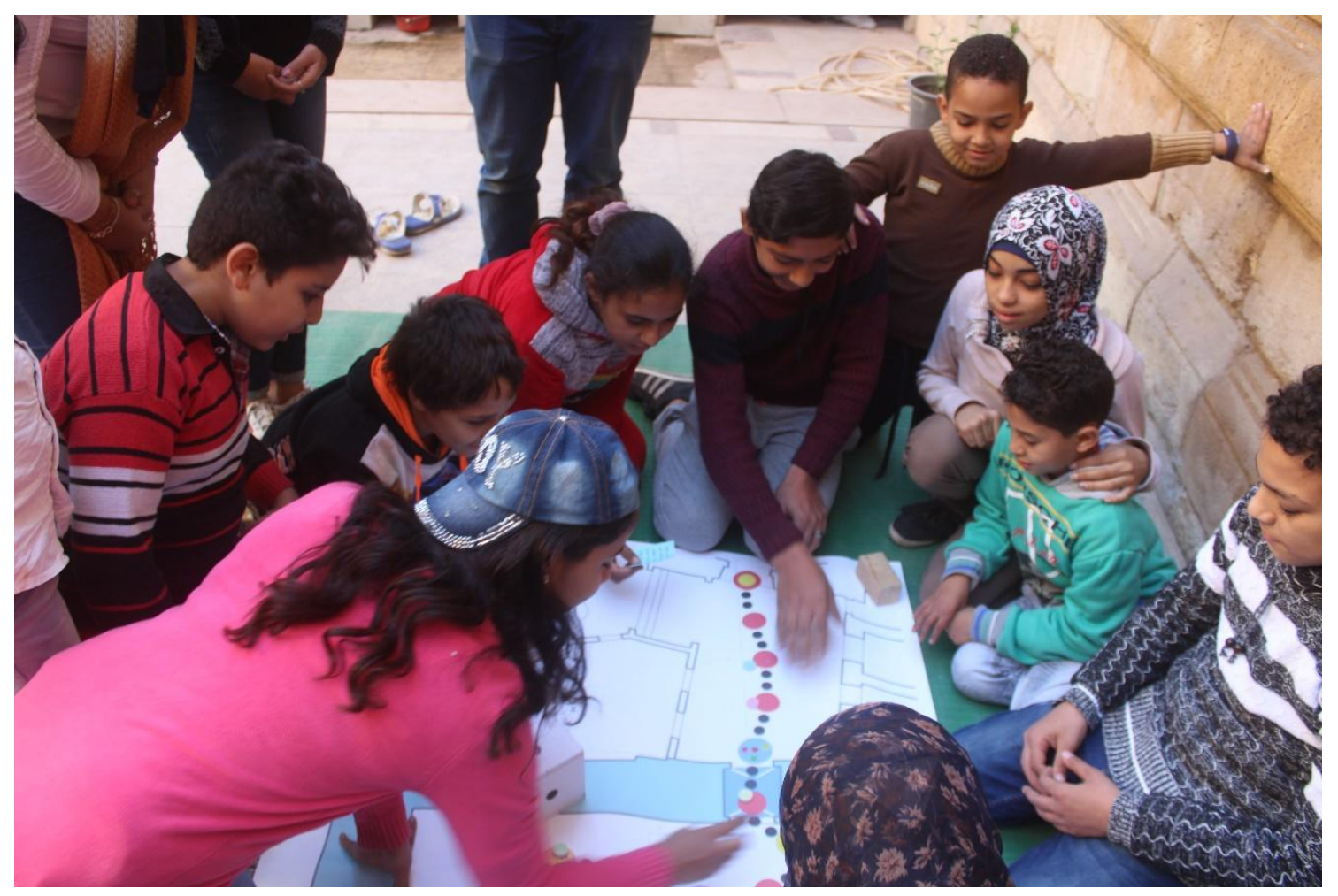

Figure 8. Shafi'i Dome Game - Spend Your Day in Khalifa 2018 @ Athar Lina

We have also used the opportunity to promote our own work and fundraise for our Khalifa Heritage Summer Camp for Kids which until 2018 was mostly funded from the revenue of this festival.

SDYK has always been a collaborative effort. The women of al-Khalifa have cooked for us, its men and youth have helped ensure that the day runs smoothly, and its artisans and shopkeepers have exhibited their products and opened their shops and workshops to visitors. Al-Khalifa's children join our events in throngs and our Summer Camp students play host to the visitors and help run our tours. Organisations such as Drosos Foundation, DEDI, UNHCR, and the British Council and private entities such as AIC Finance have funded it. We have partnered with charities such as Mashrou3 Kheir, local neighbourhood schools, universities such as Ain Shams University, and initiatives such as Nafas and Cairo Sketchers. For two years, we organised the event within a larger celebration featuring close to ten other heritage initiatives - as partners in the Egypt Heritage Network. We have relied on the generosity and enthusiasm of tour guides, artists, performers, artisans, designers and media professionals. And most importantly, we have continued to depend on the support and partnership of the Ministry of Antiquities and Tourism. As our main governmental partner, it has liaised on our behalf with all relevant governmental entities, opened the doors of all its monuments for us, sent its antiquities inspectors down to help us and played an pivotal role in promoting the event. Cairo Governorate's support has also been invaluable, and it would not have been possible to occupy the street the way we do without their cooperation. 


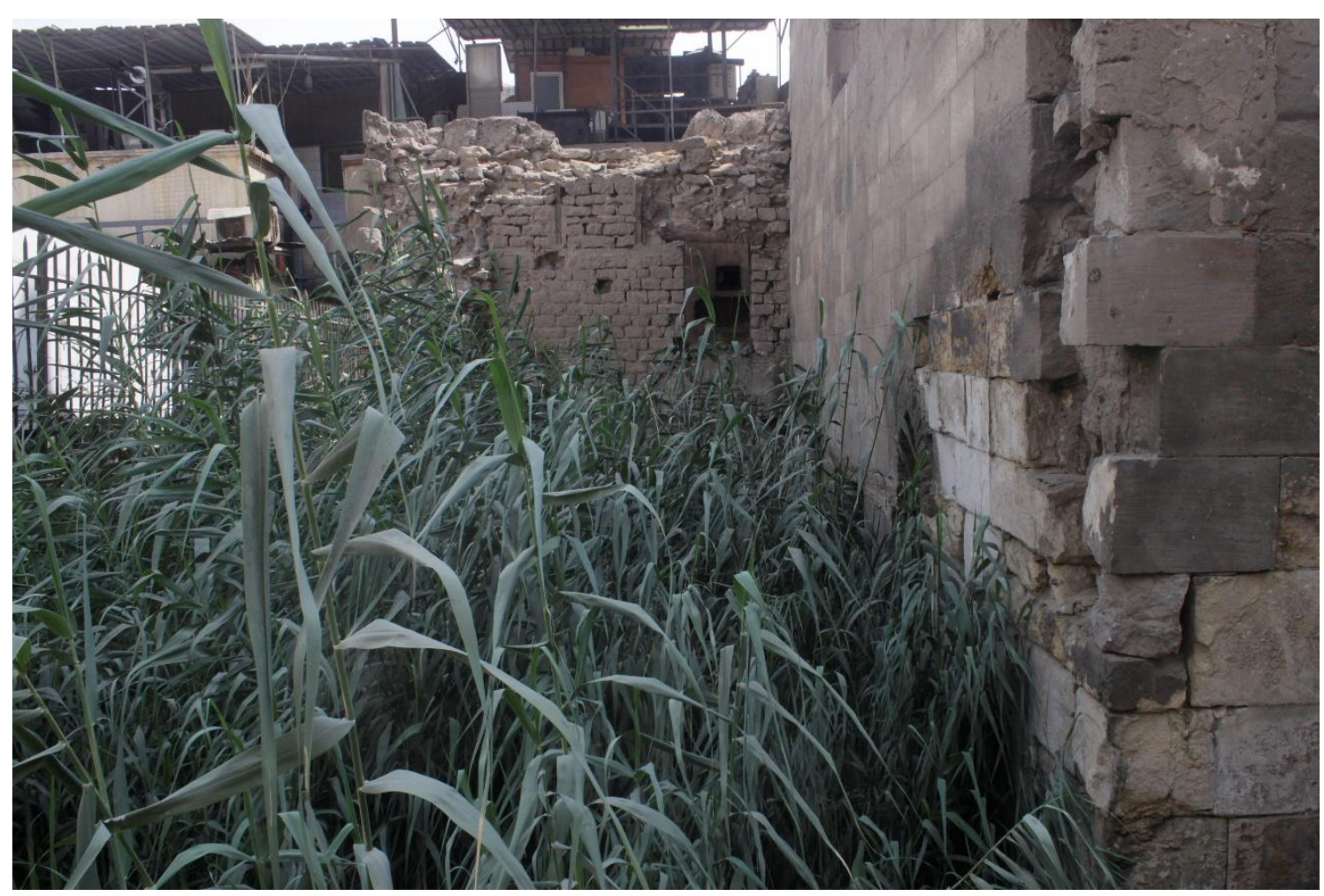

Figure 9. Groundwater damage at al-Ashraf Khalil Dome in al-Khalifa Street (C) Athar Lina

\section{Athar Lina's Urban Regeneration Program}

While SDYK is our longest running public space program, it is not the only one. Since 2016, we have focused on issues of groundwater and waste management in a twopronged approach. We work on the wider issue with the representative governmental authority, doing the required research to propose meaningful fundamental solutions that could inform decision makers. We also try to identify areas that we can intervene in. These tend to be local interventions in disused open spaces.

For example, high groundwater causes rising salt damp that damages buildings and affects health. We soon ascertained that this water, which is so high it inundates basements and heritage sites, is mostly the result of seepage from supply and sewage networks and that it is vital that they are repaired, not just in al-Khalifa but also in adjacent neighbourhoods. Our advocacy efforts with the government have resulted in the Ministry of Housing commissioning a study and leading the current governmental efforts to lower the groundwater level.

We ourselves worked on techniques to extract this water and reuse it. We installed two systems for the reuse of groundwater for cleaning and irrigation; in a private building that we currently use as our headquarters and in a local mosque yard. We also designed a 3000 sqm park to be watered and cleaned using groundwater and are currently collaborating with Cairo Governorate on its construction. ${ }^{4}$ In order to

\footnotetext{
${ }^{4}$ Khalifa Heritage and Environment Park design is in collaboration with the Egyptian firm, A for Architecture and was made possible through funding from the American Research Centre in Egypt and the US Embassy in Cairo and with additional technical support from the US Forest Service.
} 
Heritage in the street

design the park, Athar Lina conducted a needs assessment and accessibility studies through field surveys and participatory workshops with youth, women, and children.

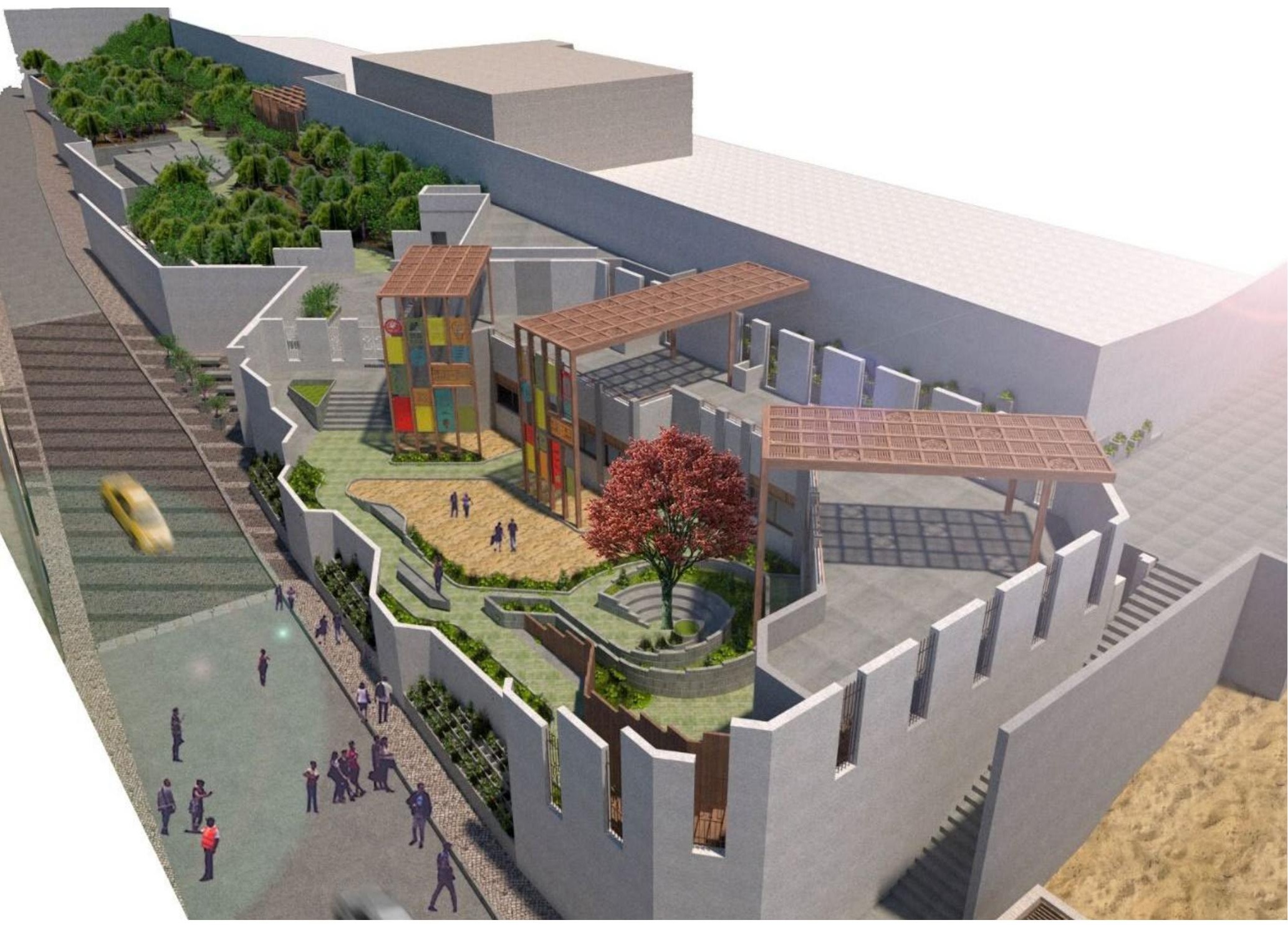

Figure 10. Proposed design for al-Khalifa Heritage and Environment Park @ Athar Lina

Implementation of Phase I is funded by Cairo Governorate and of Phase 2 by the Netherlands Embassy in Cairo.

250 | The Journal of Public Space, 6(I), 202I| ISSN 2206-9658

City Space Architecture / UN-Habitat 

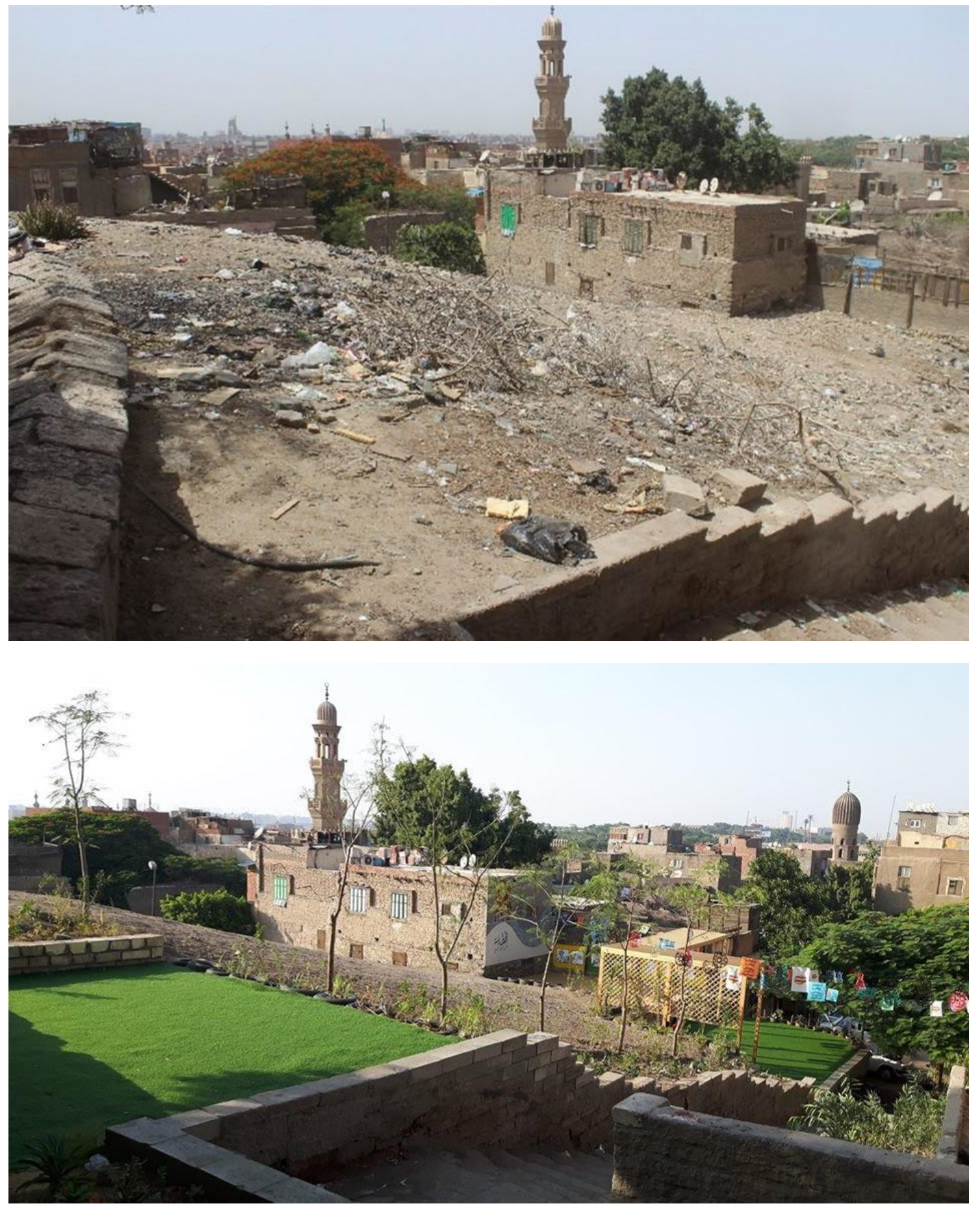

Figure II and I2. Al-Hattaba Community Garden before and after construction @ Athar Lina

\section{Al-Hattaba - a historic neighbourhood threatened with demolition} We have also worked with Cairo Governorate to clean and rehabilitate other abandoned sites for recreational purposes. So far, two sites have been converted into football pitches and a third into a community garden. The community garden is in the neighbourhood of al-Hattaba which, as mentioned above, is currently threatened with demolition. This historic neighbourhood is the victim of the inability of the current 
strategy for informal settlements to differentiate between dilapidated historic sites and unsafe informal settlements. What adds insult to injury is the fact that the historic homes of al-Hattaba are in such a poor state because for almost 50 years, their owners have been prevented from renovating them by the State. In a misguided attempt of the State to free the historic Cairo Citadel from what it deemed as encroachments, the Egyptian Government declared this neighbourhood an evacuation zone as early as the 1970s, banned construction and renovation and left the area to fall apart. In identifying neighbourhoods such as al-Hattaba (north of the Citadel) and 'Arab al-Yasar (south of the Citadel) as encroachments, the State ignores historical evidence that dates the urban fabric of these areas at latest to the $19^{\text {th }}$ century and their inception at latest to the $15^{\text {th }}$ century.
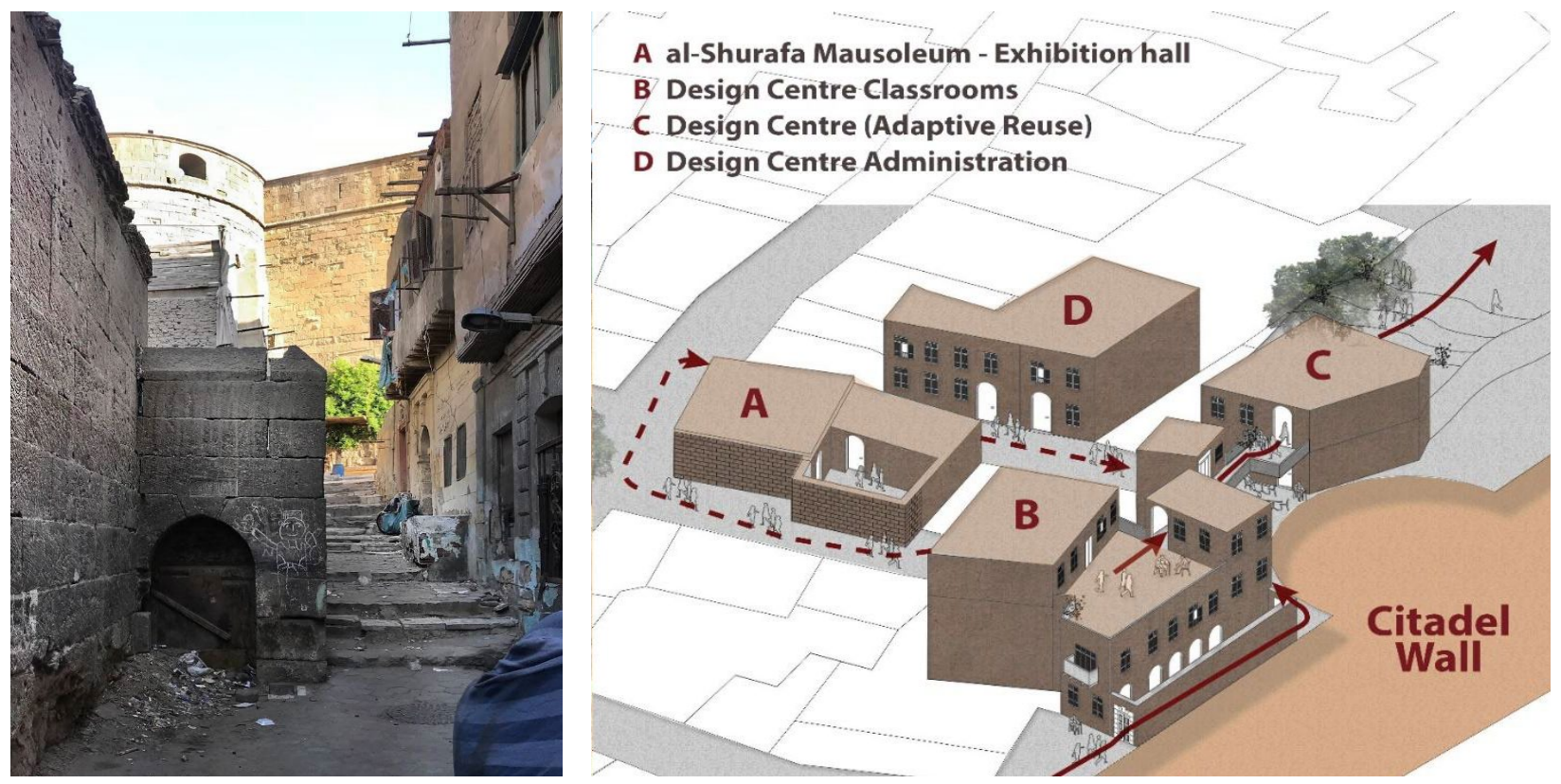

Figure I3 and 14. Upgrade proposal for al-Shurafa Mausoleum and its surroundings in al-Hattaba (C Athar Lina

Since 2018, we have advocated for the preservation of al-Hattaba. We prepared an alternative development plan for its preservation and regeneration as a historic residential craft neighbourhood that lies on the tourist path from Cairo Citadel to the iconic mosques of Sultan Hasan and al-Rifa'i. We worked on interventions such as constructing a community garden, and the conservation of a $15^{\text {th }}$ century listed building ${ }^{5}$. We have also studied the economic potential of the neighbourhood, focusing on heritage industries as a means for income generation. Through our heritage industries program, the Athar Lina Heritage Design Thinking School, ${ }^{6}$ we have designed and executed craft products, heritage tours and interactive family events inspired by alHattaba and in collaboration with its residents and artisans.

\footnotetext{
${ }^{5}$ The community garden was funded by PepsiCo Egypt. Al-Shurafa Shrine Conservation Project started in 2020 and is implemented in partnership with the Ministry of Tourism and Antiquities with funding from the American Research Centre in Cairo.

${ }^{6}$ Started in 2018 with funding from Drosos Foundation and implemented in partnership with the Ministry of Tourism and Antiquities.
} 


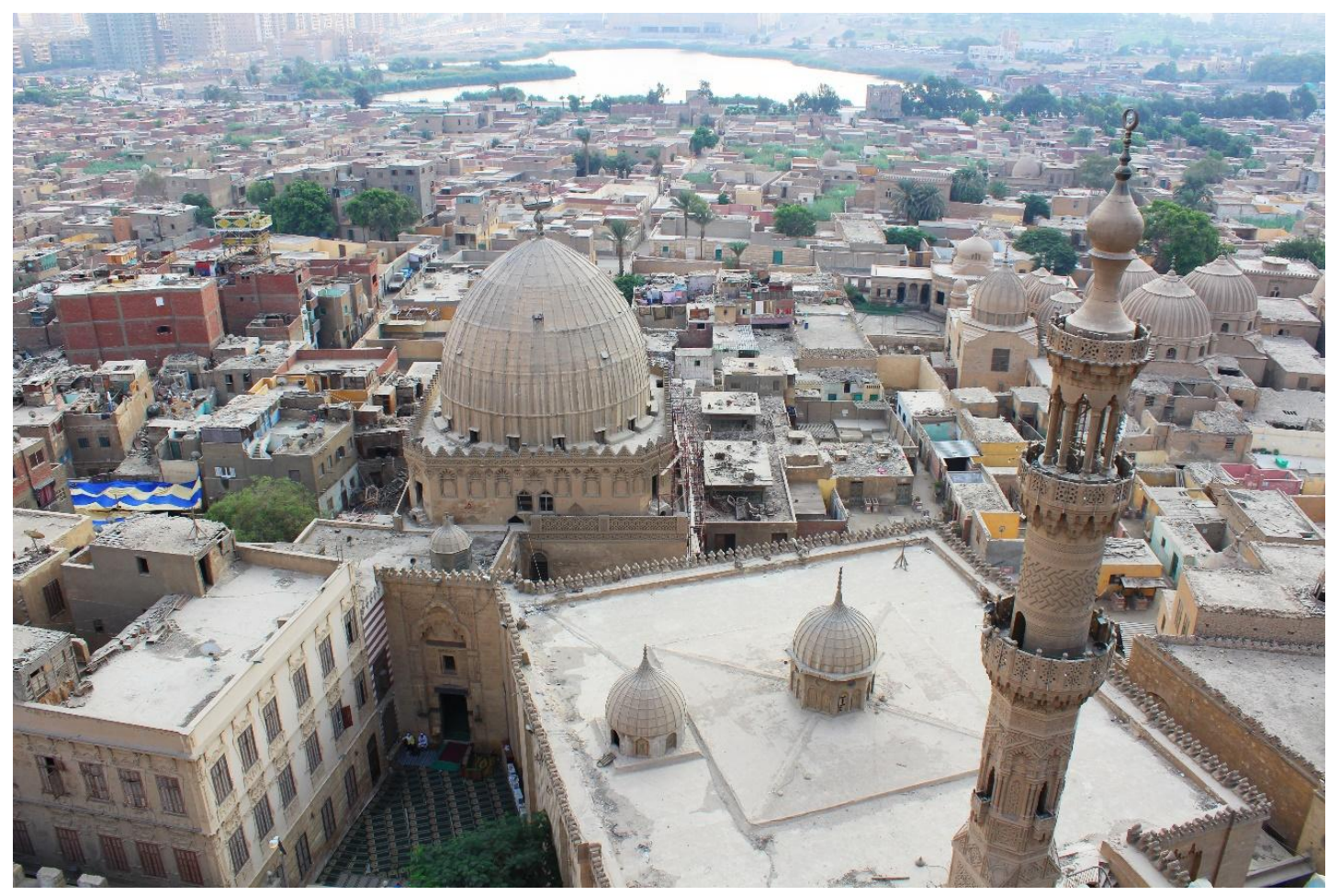

Figure I5. Al-Imam al-Shafi' Mausoleum with al-Shafi'i cemetery and 'Ayn al-Sira Park in the background (C) Athar Lina

\section{Al-Imam al-Shafi'i Cemetery: Athar Lina's third focus area}

Finally, at the core of our work in our third focus area, al-Imam al-Shafi'i neighbourhood, is the conservation of the $13^{\text {th }}$ century al-Imam al-Shafi'i Dome. ${ }^{7}$ Our challenge here is to promote cultural appreciation of al-Shafi'i Dome that enriches its standing as a destination for religious tourism. It is also to raise awareness of the historic nature of these cemeteries as a mix of life and death. Art is used here to convey the complexity of this unconventional cemetery that has been the home of many since the $9^{\text {th }}$ century. We have partnered with storyteller Chirine el-Ansary to share this nuanced narrative through storytelling walks. We also worked with designer and street artist Adham Bakry to design and implement a series of murals that constitute stops in a tour for independent travellers. The murals are linked to QR codes with information on the history of the cemetery.

\section{Policy-related issues}

Of course, not everything has been clear sailing. Generally speaking, civil society's access to public space has fluctuated drastically in the last decade. In terms of governance and advocacy, we went from the no-holds-barred years of $201 \mathrm{I}$ and 2012 when anything was possible, but nothing got done from the Government's side, to a gradual increase in regulation and State control.

\footnotetext{
${ }^{7}$ Implemented between 2016 and 2021 in partnership with the Ministry of Antiquities and Tourism and with funding from the Ambassadors' Fund for Cultural Preservation and additional funding from the Barakat Trust and the Prince Claus Fund.
} 


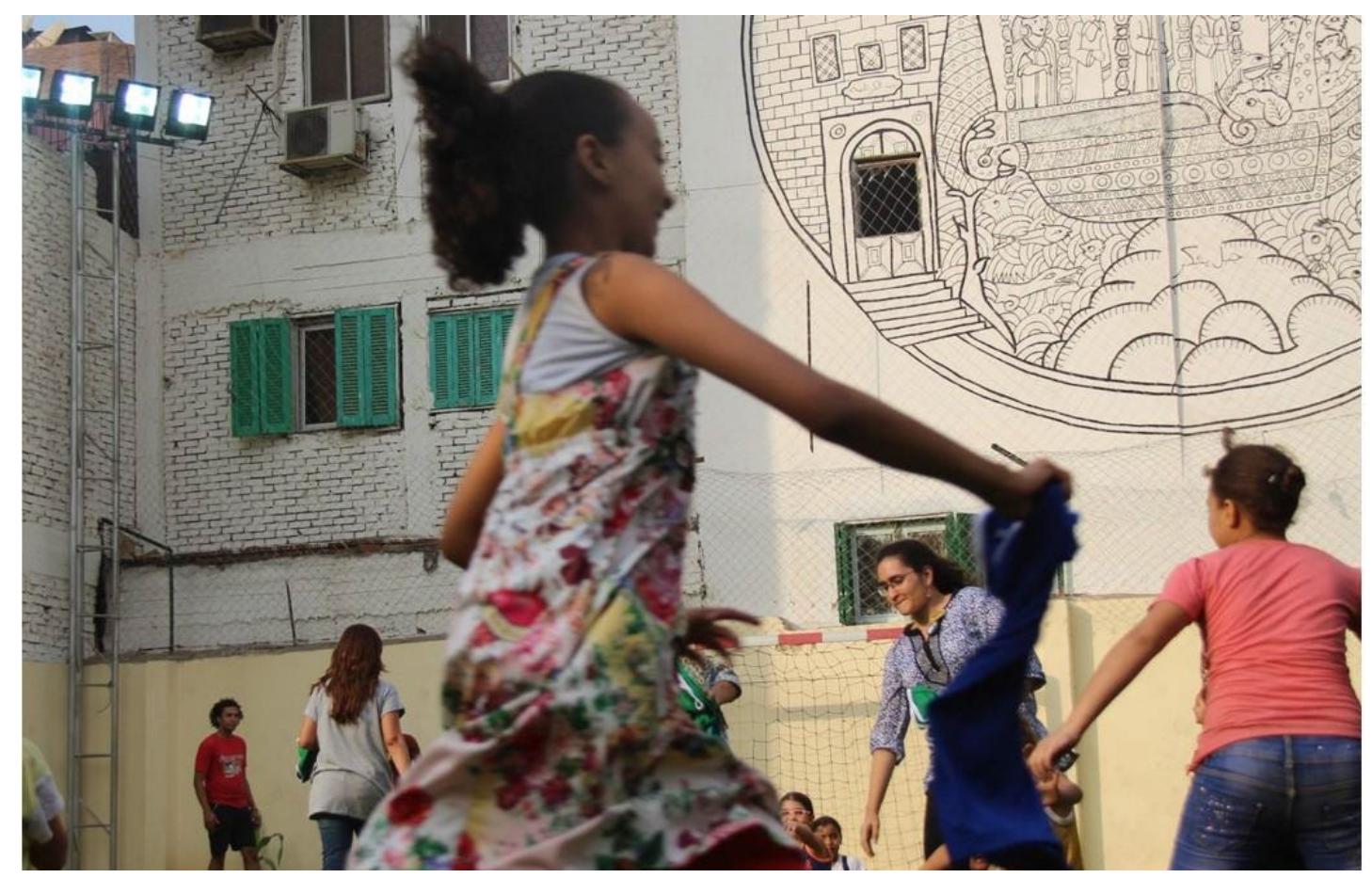

Figure 16. Children playing in Darb al-Husr Football Pitch designed by Athar Lina and implemented by Cairo Governorate (C) Athar Lina

Another issue facing us today is the need to reconcile our work with the current State preference for ambitious top-down interventions in which there is little to no consultation with civil society. This is reflected in the ability to organise, mobilise and shape public space. On the bright side, Athar Lina is fortunate because its work comes under a mandate of heritage and conservation and as such, is seen as a benign activity that the State encourages civil society to participate in. The antiquities authorities' support is invaluable in this regard and it is the result of an incremental process of trustbuilding that started in 2012 .

$201 \mathrm{I}$ brought with it the establishment of an independent ministry, the Ministry of Antiquities, responsible for heritage. Ironically, due to budget cuts in response to waning tourism, it had almost no budget for the large conservation projects it considered its main responsibility. Furthermore, with the fluidity and openness of $20 \mathrm{II}$, came an interest in participation and a realisation of the role people could - and should - play in benefiting and caring for their heritage. This meant that when we approached the antiquities authorities in 2012 to partner on softer approaches to heritage management that include participation and education, their response was positive, if not enthusiastic. Our work also coincided with UNESCO's Urban Regeneration of Historic Cairo (URHC) research project that aimed to orient the Egyptian State towards a more integrated approach to heritage that dealt with historic urban fabric rather than individual monuments and promoted citizen participation and right to heritage.

URHC's activities also brought together a wider range of heritage stakeholders and promoted a participatory, integrated, inter-sectorial and sustainable heritage approach. Finally, the surge of initiatives, practices and advocacy groups concerned with heritage signalled the birth of a "Brave New World" for Egyptian heritage. 


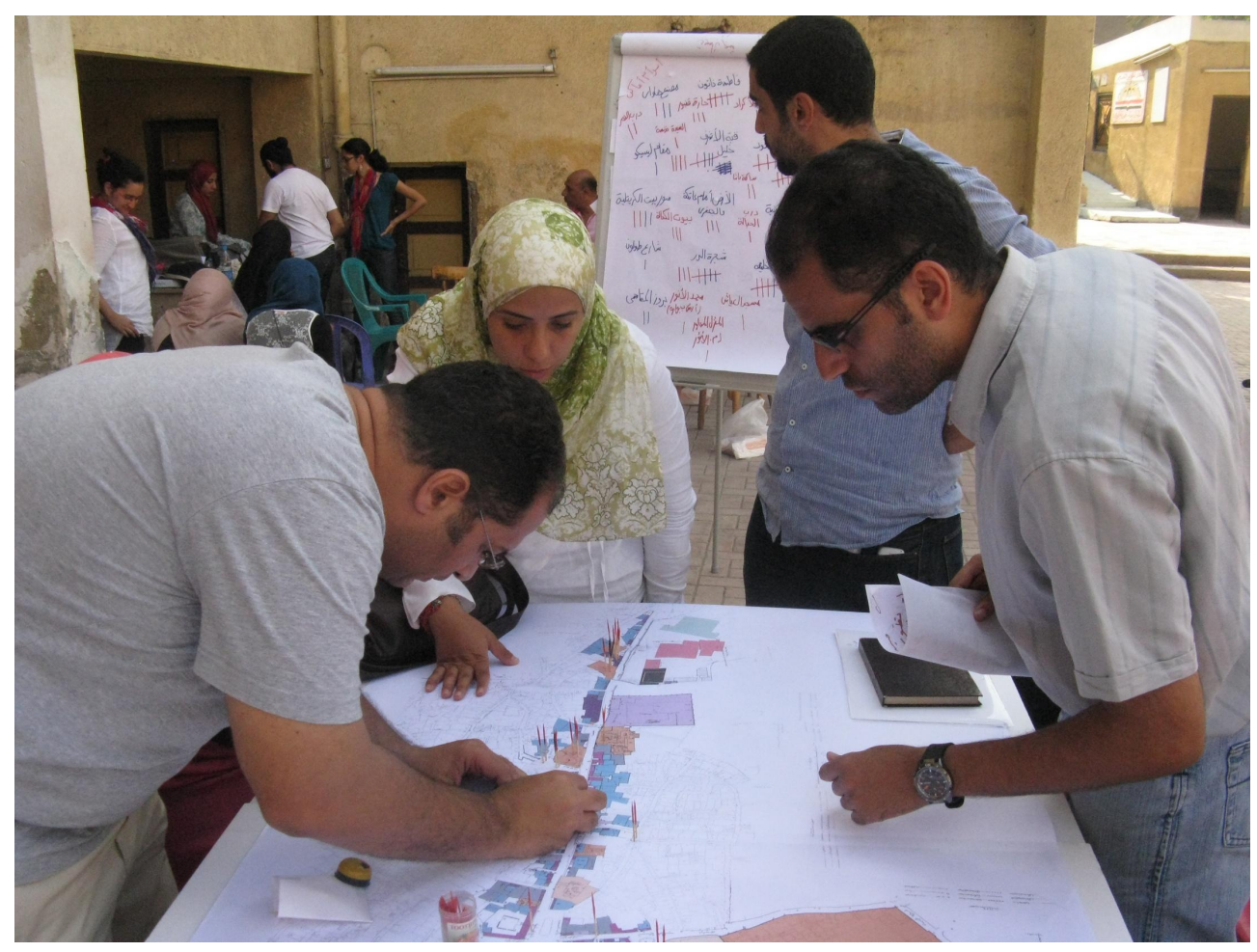

Figure 17. Collaborative mapping exercise in 2012 including a government official, academic and urban development expert ( ) Athar Lina

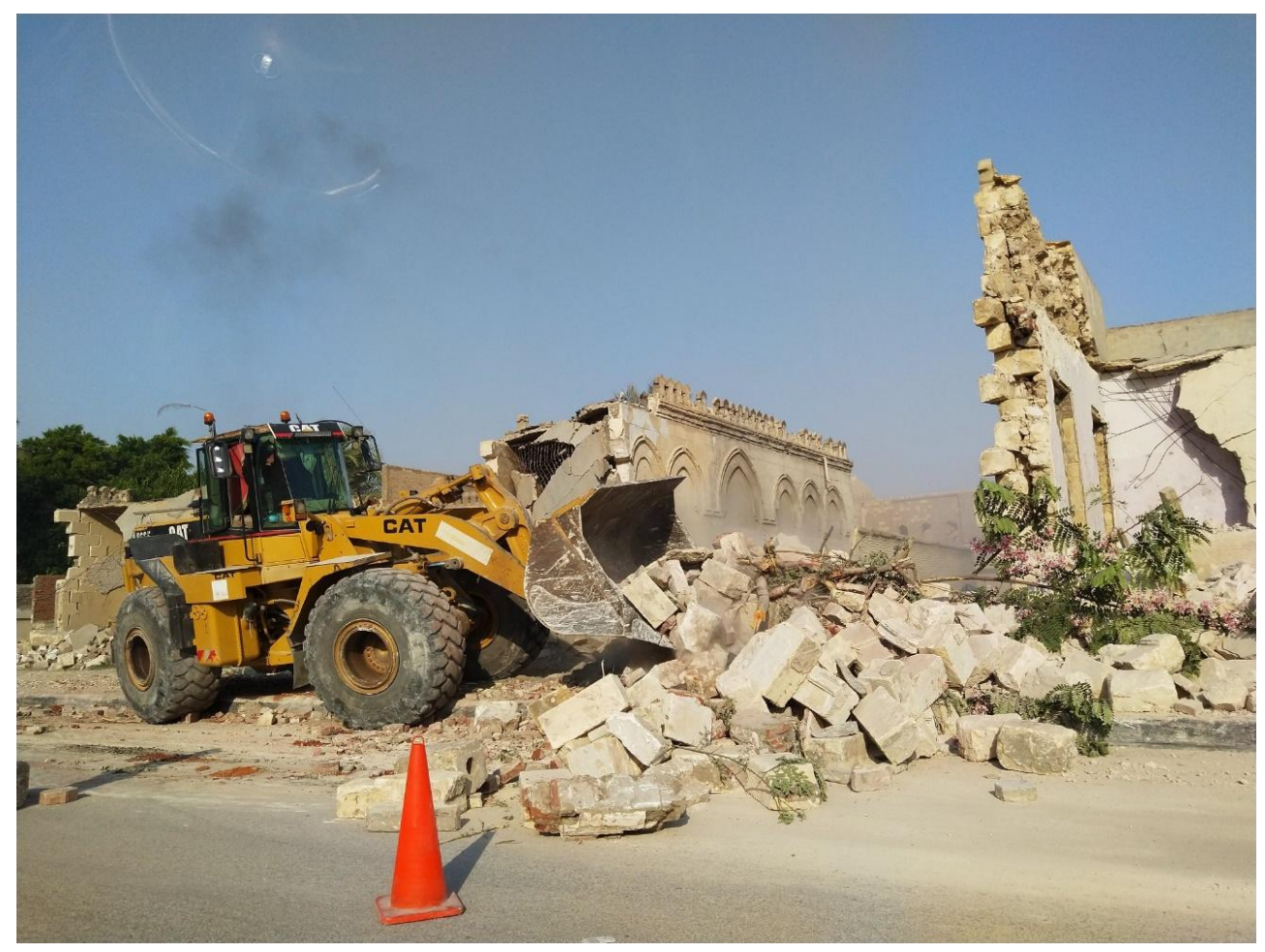

Figure 18. Demolition of sections of Cairo's historic cemetery to make room for bridges and widen roads 
By 2019, the map of heritage management had changed quite drastically. While many professional practices and non-governmental actors continue to function and adopt an integrated participatory approach, new State policies tend to gravitate towards ambitious projects that are fast, large and top down. The current work on widening streets and building bridges, many of which cut through historic neighbourhoods, is a case in point. The State has also tightened its control over civil society. Access to public space, and funding and the ability to work directly with communities is monitored and controlled. On a positive note, this means that the State has assumed more responsibility for the city. For example, in al-Khalifa Street, the government is currently implementing a massive project to resolve the issue of groundwater, develop and promote a tourist itinerary and upgrade streets and buildings along that path.

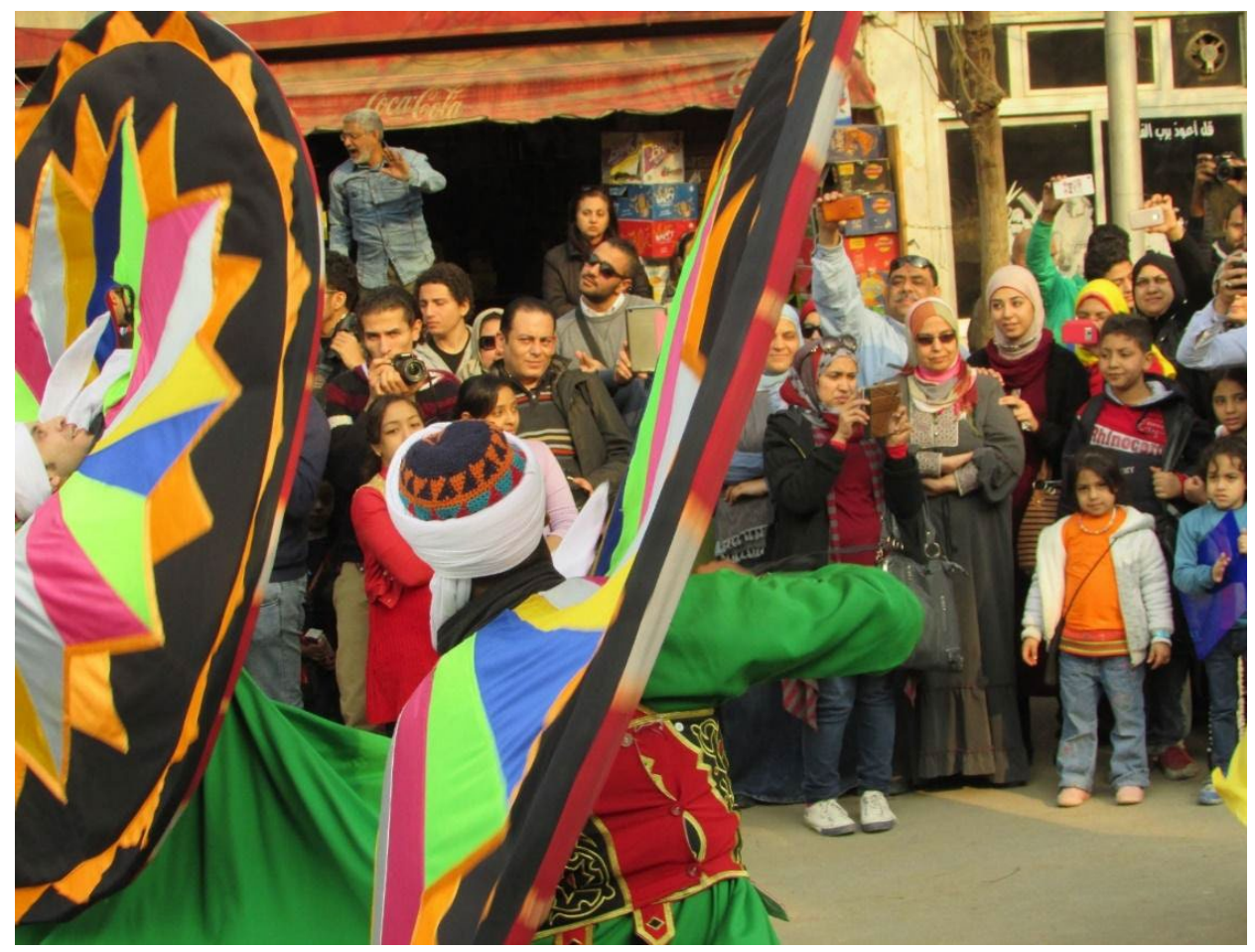

19. Tannura Performance in Ibn Tulun Street (C) Athar Lina

\section{Now what?}

The paint on 'Am Mustafa's shisha-smoking women is now peeling and Agnes has come back to redo it, but with a twist. She now proposes to link it to an augmented reality animation. This is not a one-off attempt to link al-Khalifa to the virtual world. The QR codes of the self-guided tours of al-Shafi'i Cemetery are part of an integrated website promoting al-Khalifa launched at the end of $2020 .^{8} \mathrm{Al}-\mathrm{Khalifa}$, along with the rest of the world, seems to be going online. But no virtual reality, however sophisticated, is a substitute for the smells, sounds, tastes and sights of the tour de force that is Historic Cairo.

\footnotetext{
${ }^{8}$ Al-Khalifa's website (https://khalifa.atharlina.com/) includes information on its heritage sites, history, oral history, people and crafts. It promotes Khalifa inspired products and activities and even includes downloadable heritage activity packs for children. More detailed information of Athar Lina's work can be found at (https://atharlina.com/).
} 